\title{
Haloquadratum walsbyi gen. nov., sp. nov., the square haloarchaeon of Walsby, isolated from saltern crystallizers in Australia and Spain
}

Correspondence Mike L. Dyall-Smith mlds@unimelb.edu.au

\author{
David G. Burns, ${ }^{1}$ Peter H. Janssen, ${ }^{1}$ Takashi Itoh, ${ }^{2}$ Masahiro Kamekura, ${ }^{3}$ \\ Zhuo Li, ${ }^{4}$ Grant Jensen, ${ }^{4}$ Francisco Rodríguez-Valera, ${ }^{5}$ Henk Bolhuis ${ }^{6}$ \\ and Mike L. Dyall-Smith ${ }^{1}$ \\ ${ }^{1}$ Department of Microbiology and Immunology, University of Melbourne, Victoria 3010, Australia \\ 2Japan Collection of Microorganisms, RIKEN BioResource Center, Saitama 351-0198, Japan \\ ${ }^{3}$ Noda Institute for Scientific Research, 399 Noda, Noda-shi, Chiba-ken 278-0037, Japan \\ ${ }^{4}$ California Institute of Technology, Mail code 114-96, Pasadena, CA 91125, USA \\ ${ }^{5}$ Universidad Miguel Hernandez, 03550 San Juan de Alicante, Spain \\ ${ }^{6}$ Department of Microbial Ecology, University of Groningen, 9751 NN Haren (Gn), \\ The Netherlands
}

\begin{abstract}
Strains $\mathrm{C}_{23}{ }^{\top}$ and HBSQ001 were isolated from solar salterns and are novel square-shaped, aerobic, extremely halophilic members of the domain Archaea and family Halobacteriaceae. Cells stained Gram-negative and grew optimally in media containing $18 \%$ salts at around neutral $\mathrm{pH}$. $\mathrm{Mg}^{2+}$ is not required. The DNA G+C content of both isolates was $46.9 \mathrm{~mol} \%$ and DNA-DNA cross-hybridization showed a relatedness of $80 \%$. Their $16 \mathrm{~S}$ rRNA gene sequences showed only 2 nucleotide differences ( $99.9 \%$ identity) and phylogenetic tree reconstructions with other recognized members of the Halobacteriaceae indicated that they formed a distinct clade, with the closest relative being Halogeometricum borinquense PR $3^{\top}$ ( $91.2 \%$ sequence identity). The major polar glycolipid of both isolates was the sulfated diglycosyl diether lipid S-DGD-1. Electron cryomicrosopy of whole cells revealed similar internal structures, such as gas vesicles and polyhydroxyalkanoate granules, but the cell wall of isolate HBSQ001 displayed a more complex $\mathrm{S}$-layer compared with that of isolate $\mathrm{C} 23^{\top}$. The phenotypic characterization and phylogenetic data support the placement of isolates $\mathrm{C}_{2} 3^{\top}$ and HBSQ001 in a novel species in a new genus within the Halobacteriaceae, for which we propose the name Haloquadratum walsbyi gen. nov., sp. nov. The type strain of Haloquadratum walsbyi is $\mathrm{C}_{23}{ }^{\top}\left(=\mathrm{JCM} 12705^{\top}=\mathrm{DSM} 16854^{\top}\right)$.
\end{abstract}

\section{INTRODUCTION}

Salt lakes occur worldwide and present a diverse range of environmental conditions to the organisms dwelling within them, including substantial variation in $\mathrm{pH}$, salinity (including variations in ionic composition) and temperature (reviewed by Oren, 2002). At salinities approaching saturation, the majority of micro-organisms are extremely halophilic archaea belonging to the family Halobacteriaceae (Oren, 2002) and, at high cell densities, the carotenoid pigments of these haloarchaea often give such waters a distinctive pink colour. Certain bacteria, such as strains of

Abbreviations: $\mathrm{PHA}$, polyhydroxyalkanoate; SHOW, square haloarchaea of Walsby.

The GenBank/EMBL/DDBJ accession numbers for the 16S rRNA gene sequences of isolates $\mathrm{C}_{2} 3^{\top}$ and HBSO001 are respectively AY676200 and AM180088.
Salinibacter and Salicola, may also be present, but are usually a minor component (Antón et al., 2000, 2002; Maturrano et al., 2006).

In 1980, the extraordinary square haloarchaea of Walsby (SHOW) were first described in water samples taken from hypersaline pools (sabkha) near the Red Sea (Walsby, 1980). The cells were regular, extremely thin squares that contained gas vesicles and often formed extended sheets (Stoeckenius, 1981; Parkes \& Walsby, 1981). Such cells were commonly found as the dominant cell type in these and other hypersaline waters, including natural salt lakes and saltern crystallizer ponds, and were able to be characterized by $16 \mathrm{~S}$ rRNA gene PCR amplification and sequencing (Benlloch et al., 1995, 2001). The sequence information enabled the development of specific fluorescent in situ hybridization (FISH) probes (Antón et al., 1999) and, later, sequence tags to screen cultures by PCR (Burns et al., 2004a). However, it 
was not until 2004 that the first isolates were obtained in pure culture, by two independent groups (Bolhuis et al., 2004; Burns et al., 2004b). Recently, the genome sequence of strain HBSQ001 has been published (Bolhuis et al., 2006).

In this study, the phenotypic and phylogenetic characteristics of two different SHOW isolates were determined. These indicated that they belong to a novel species and a new genus within the Halobacteriaceae.

\section{METHODS}

Strains. Isolation and preliminary descriptions of the two SHOW isolates $\mathrm{C}_{2} 3^{\mathrm{T}} \quad\left(=\mathrm{JCM} \quad 12705^{\mathrm{T}}=\mathrm{DSM} \quad 16854^{\mathrm{T}}\right)$ and HBSQ001 ( = JCM 12895=DSM 16790) have been reported previously (Burns et al., 2004b; Bolhuis et al., 2004). Other reference strains included in this study were Haloferax mediterranei ATCC $33500^{\mathrm{T}}$, Haloferax volcanii NCIMB 2012 ${ }^{\mathrm{T}}$, Halogeometricum borinquense JCM $10706^{\mathrm{T}}$, Halobacterium salinarum NRC-1 (= JCM 11081) and Haloterrigena turkmenica JCM $9101^{\mathrm{T}}$.

Media and growth conditions. Two types of characterization media were used. Medium CM1 contained (per litre): $995 \mathrm{ml} \mathrm{25 \%}$ $(\mathrm{w} / \mathrm{v})$ salt water $(\mathrm{SW})$ and $5 \mathrm{ml} 23 \%(\mathrm{w} / \mathrm{v})$ MGM. The recipes for SW and MGM have been published previously (Nuttall \& DyallSmith, 1993; Porter et al., 2005) and are available online in The Halohandbook (Dyall-Smith, 2006). The solution was autoclaved $\left(121^{\circ} \mathrm{C}, 101 \mathrm{kPa}, 15 \mathrm{~min}\right)$ and the following were added from filtersterilized stock solutions: $5 \mathrm{ml} 1 \mathrm{M} \mathrm{NH} \mathrm{Nl}_{4}, 2 \mathrm{ml} 0.5 \mathrm{M} \mathrm{K}_{2} \mathrm{HPO}_{4}$, $1 \mathrm{ml}$ SL10 trace metal solution (Widdel et al., 1983), $3 \mathrm{ml} \mathrm{Vit10}$ vitamin solution (Vit10 is a combination of $0.25 \mathrm{ml}$ vitamin solution 1 and $0.75 \mathrm{ml}$ vitamin solution $2 \mathrm{ml}^{-1}$ as described in Janssen et al., 1997) and $4.4 \mathrm{ml} 25 \%(\mathrm{w} / \mathrm{v})$ sodium pyruvate (10 mM final concentration). Medium CM2 was identical to CM1 except that the base medium comprised (per litre) $950 \mathrm{ml} 25 \%(\mathrm{w} / \mathrm{v})$ SW and $50 \mathrm{ml} 23 \%$ (w/v) MGM. Medium MGM was prepared as described in The Halohandbook always using $23 \%$ salts. Solid MGM media used unwashed $1.5 \%(\mathrm{w} / \mathrm{v})$ agar (Difco-Bacto) as the gelling agent. All cultures were incubated unshaken at $37^{\circ} \mathrm{C}$, unless stated otherwise. Growth of liquid cultures was followed spectrophotometrically (Bausch \& Lomb Spectronic 20) at $600 \mathrm{~nm}$.

Light microscopy and electron cryomicroscopy. Light microscopy was performed with a Leitz Diaplan microscope fitted with phase-contrast optics and was used to check cell morphology, Gram stain and motility. For electron cryomicroscopy, a $4 \mu \mathrm{l}$ drop of cell culture was applied to glow-discharged Quantifoil grids (Quantifoil Micro Tools) and then plunge-frozen in liquid ethane using a Vitrobot (FEI). Images were recorded in an FEG G2 Polara FEI transmission electron microscope operating at $300 \mathrm{keV}$. Liquid nitrogen was used as the cryogen. For the projection images shown in Fig. 1, the defocus was $\sim 30 \mu \mathrm{m}$.

Electron cryotomography. For the tomographic slices (in Fig. 1e, g), tilt series were acquired from $-58^{\circ}$ to $+58^{\circ}$ in steps of $2^{\circ}$ with a total dose of $\sim 50$ electrons $\AA^{-2}$ for HBSQ001 and $\sim 80$ electrons $\AA^{-2}$ for $\mathrm{C} 23^{\mathrm{T}}$, an image pixel size of $1.2 \mathrm{~nm}$, an energy slit-width of $20 \mathrm{eV}$ and a defocus of $\sim 30 \mu \mathrm{m}$. Three-dimensional reconstructions were calculated using IMOD using images binned twofold (McIntosh et al., 2005). For the measurement of distances between membrane layers of $\mathrm{C} 23^{\mathrm{T}}$ and HBSQ001, tomograms of cells of strains $\mathrm{C}_{2} 3^{\mathrm{T}}$ and HBSQ001 were first segmented manually to generate a shell following the outer layer of cytoplasmic membrane (position of zero). The shell surface consisted of thousands of small triangles. The density values along the normal line of each triangle plane were then measured and averaged.
Phenotypic tests. The minimal standards for the description of new taxa within the order Halobacteriales were followed (Oren et al., 1997). The methods have been described previously (Torreblanca et al., 1986; Gutierrez et al., 2002) and are based on standard microbiological protocols (Gerhardt et al., 1994) but adapted for use with extremely halophilic micro-organisms. Variations are described below. The tests performed are included in the species description. $H f x$. volcanii NCIMB $2012^{\mathrm{T}}$ was used as a control in most tests.

For the hydrolysis of casein, cells were cultured for 1 week in $10 \mathrm{ml}$ medium CM1 with a low level $(5 \mathrm{mM})$ of pyruvate and with $0.5 \%$ $(\mathrm{w} / \mathrm{v})$ casein from a filter-sterilized stock solution. Azocasein $(0.1 \% \mathrm{w} /$ v) was then added and the cultures were incubated for a further 9 days. Cells and salt-precipitated casein (and azocasein) were removed by centrifugation and azocasein hydrolysis was measured spectrophotometrically (LKB Biochrom Ultrospec II) at $405 \mathrm{~nm}$.

For substrate utilization tests, cells were inoculated into medium CM1 containing $10 \mathrm{mM}$ substrate (see species description) except for cellulose, chitin and starch, which were added at $0.1 \%(\mathrm{w} / \mathrm{v})$. In cultures that grew, the final $\mathrm{pH}$ was measured using a calibrated $\mathrm{pH}$ meter and compared with the uninoculated control of the same substrate.

For testing antibiotic sensitivity, cells were inoculated into CM2 media with the addition of $10 \mathrm{mM}$ pyruvate and $50 \mu \mathrm{g}$ antibiotic $\mathrm{ml}^{-1}$. Cells were incubated for 3 weeks at $37^{\circ} \mathrm{C}$.

Anaerobic respiration was tested using medium $\mathrm{CM} 1$, but without MGM, and with only one-tenth the level of $\mathrm{NH}_{4} \mathrm{Cl}$. DMSO or $\mathrm{NaNO}_{3}$ or neither (to test for fermentation) were added to a final concentration of $10 \mathrm{mM}$. Media were dispensed aseptically into $30 \mathrm{ml}$ plastic tubes, each containing an inverted Durham tube. Cultures were incubated under either anaerobic conditions using Anaerogen sachets (Oxoid) or aerobically, for 3 weeks at $37^{\circ} \mathrm{C}$ without shaking, after which the presence of nitrogen gas bubbles and nitrite were determined.

For the indole test, cells were grown in medium CM1 with the addition of $1 \%(\mathrm{w} / \mathrm{v})$ peptone for 1 week at $37^{\circ} \mathrm{C}$ before testing for indole using Kovacs' reagent.

Growth at different temperatures was tested in CM2 medium. Cultures were made in duplicate and incubated at $4,25,30,37,40,42,45$ and $55^{\circ} \mathrm{C}$ for 2 weeks. Growth was followed spectrophotometrically at $600 \mathrm{~nm}$.

For growth at different salinities, SW solutions of increasing salinity ( $2 \%$ increments) were prepared, keeping the same ratio of salts as in $30 \%$ SW (above). The supplements normally added to CM2 medium were added to each salinity increment. After inoculation, cultures were incubated for up to 3 weeks at $37^{\circ} \mathrm{C}$.

The magnesium requirement was assessed by increasing $\mathrm{Mg}^{2+}$ against a constant $\mathrm{NaCl}$ concentration. Solutions contained $2.37 \mathrm{M} \mathrm{NaCl}$ and $0.08 \mathrm{M} \mathrm{KCl}$ and either $\mathrm{MgCl}_{2}$ or $\mathrm{MgSO}_{4}$ ranging from 0 to $1.5 \mathrm{M}$ in steps of $0,0.2,0.4,0.6,0.8,1.0,1.25,1.5 \mathrm{M}$. MGM was added to onetenth the usual concentration $\left(0.5 \mathrm{~g}\right.$ peptone, $0.1 \mathrm{~g}$ yeast extract $\mathrm{l}^{-1}$ ) before autoclaving. Cultures were incubated, unshaken, at $37^{\circ} \mathrm{C}$ for 3 weeks.

Lipids were extracted with chloroform/methanol and separated by TLC as described previously (Kamekura, 1993; Gutierrez et al., 2002).

G $+\mathbf{C}$ content and DNA-DNA hybridization. The $\mathrm{G}+\mathrm{C}$ content of whole-cell DNA was determined by HPLC (Tamaoka, 1994). Relatedness by DNA-DNA hybridization was performed by a fluorometric method (Ezaki et al., 1989).

165 rRNA gene sequencing and phylogenetic tree reconstructions. For isolate $\mathrm{C} 23^{\mathrm{T}}, 16 \mathrm{~S}$ rRNA genes were amplified by 

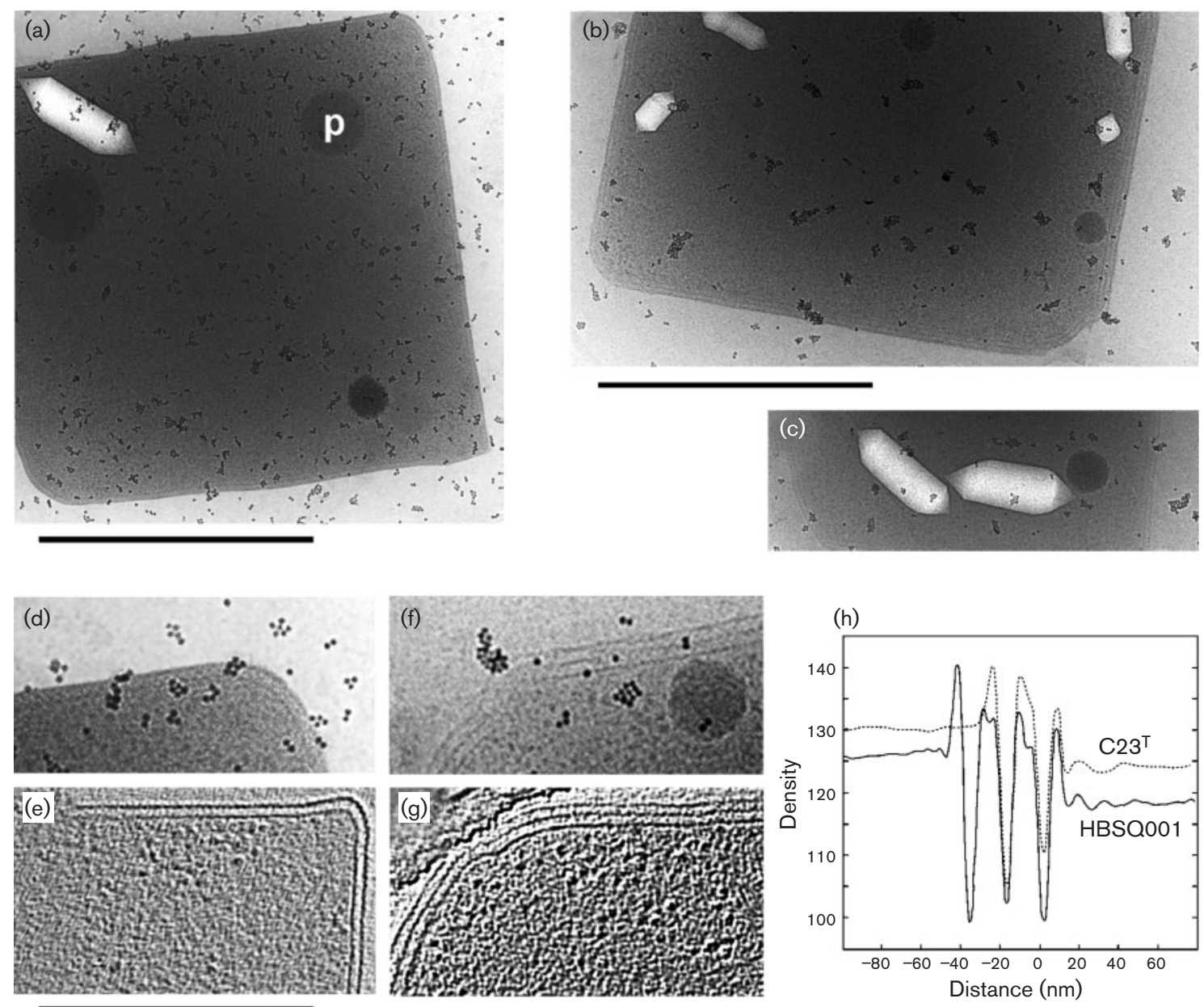

Fig. 1. Electron cryomicroscopy of $\mathrm{C}_{2} 3^{\top}$ and HBSQ001. Cells were embedded in vitreous ice and images recorded in an FEG G2 Polara FEI transmission electron microscope. (a) Cell of strain $\mathrm{C}_{2} 3^{\top}$ showing a gas vesicle and PHA granules (one is labelled p); (b) cell of strain HBSQ001 with PHA granules and immature or damaged gas vesicles; (c) mature gas vesicles of strain HBSQ001; (d) enlargement of cell wall of isolate $C 23^{\top}$ showing the membrane and S-layer structure of the cell wall; (e) $4.8 \mathrm{~nm}$ thick tomographic slice through the middle of a three-dimensional reconstruction of a cell of strain $\mathrm{C}_{2} 3^{\top}$, highlighting the bilaminar structure of the cell wall; $(f)$ enlargement of cells of strain HBSQ001 showing the trilaminar structure of the cell wall; (g) $4.8 \mathrm{~nm}$ thick tomographic slice through the middle of a cell of strain HBSQ001 showing the trilaminar cell wall; (h) measurement of distances between cell wall layers of $\mathrm{C}_{2} 3^{\top}$ (dotted line) and HBSQ001 (solid line) using densitometry across cell images taken by cryotomography (see Methods). The horizontal axis is the distance (in $\mathrm{nm}$ ) away from the cytoplasmic membrane shell. The vertical axis is the mean density value. The small black dots scattered across the images in $(a-d)$ and ( $f)$ are $10 \mathrm{~nm}$ diameter colloidal gold particles. The scale bars shown under (a) and (b) represent $1000 \mathrm{~nm}$, and (b) and (c) share the same bar. The scale bar beneath $(d)$ and $(e)(500 \mathrm{~nm})$ is the same for $(f)$ and $(g)$.

PCR and sequenced as described in Burns et al. (2004a). The $16 \mathrm{~S}$ rRNA gene sequence of isolate HBSQ001 was derived from the genome sequence (GenBank accession no. AM180088). Sequences were aligned and phylogenetic trees were constructed using programs within the ARB phylogeny package (Ludwig et al., 2004).

\section{RESULTS AND DISCUSSION}

Two SHOW strains were isolated from solar salterns, one in Australia and the other in Spain, and their general characteristics, light and electron microscopy, have been described previously (Burns et al., 2004a; Bolhuis et al.,
2004). Different isolation methods were used: isolate $\mathrm{C} 23^{\mathrm{T}}$ (Australia) was recovered using an extinction-dilution culturing technique and isolate HBSQ001 (Spain) was obtained by serial enrichment over a 2-year period. In both cases, low-nutrient media containing pyruvate were used.

Colonies took 4-8 weeks to grow on solid media. After 8 weeks, colonies were small $(0.5-1.0 \mathrm{~mm}$ diameter $)$, convex, round, with an entire edge, and intense red to pink in colour. Liquid cultures were also pink in colour, depending upon the cell density. Under optimal growth conditions, cells exhibit a perfect flat square or rectangular 
shape, around $2 \mu \mathrm{m}$ per edge and $0.2 \mu \mathrm{m}$ thick. Much larger cell aggregates were also observed; HBSQ001 displays cell sheets of up to $40 \times 40 \mu \mathrm{m}$ (Bolhuis et al., 2004) and $\mathrm{C} 23^{\mathrm{T}}$ can form sheets of at least $12 \mu \mathrm{m}$ a side (data not shown). At salinities below $\sim 23 \%$, the cell morphology deteriorates to a ragged square or other flat pleomorphs. Both strains are non-motile and stain Gram-negative. A large number of potential growth substrates were tested (see species description), but pyruvate was the only carbon source to permit reproducibly measurable growth of both isolates. Cells are oxidase- and catalase-negative using conventional testing. They do not hydrolyse starch or casein and do not show $\beta$-galactosidase activity. Indole is not produced in tryptophan-containing media. Neither strain was able to use nitrate or DMSO as an alternative electron acceptor under anaerobic conditions.

Electron cryomicroscopy resolved internal cell structures very clearly (Fig. 1). The two isolates showed similar types of gas vesicles and polyhydroxyalkanoate (PHA) granules but differed significantly in cell-wall structure. Isolate $\mathrm{C} 23^{\mathrm{T}}$ possessed a typical two-layer cell wall consisting of a simple S-layer above the cell membrane (Fig. 1a, d, e). The cell wall of isolate HBSQ001 displayed a more complex, apparently three-layered structure, unlike other haloarchaea (Fig. 1b, f, $\mathrm{g}, \mathrm{h})$. Fig. $1 \mathrm{~h}$ shows the density profiles across both cell walls. In HBSQ001, two peaks were resolved outside the cytoplasmic membrane, corresponding to two layers of surface structure. Each layer appeared $\sim 14 \mathrm{~nm}$ away from the next (peak-to-peak). In $\mathrm{C} 23^{\mathrm{T}}$, there was only one surface layer covering the cytoplasmic membrane, also $\sim 14 \mathrm{~nm}$ above the membrane.

The optimum growth temperature for both strains was $45^{\circ} \mathrm{C}$. The minimum growth temperature was $25^{\circ} \mathrm{C}$ for $\mathrm{C} 23^{\mathrm{T}}$ and $30^{\circ} \mathrm{C}$ for HBSQ001. No growth was observed at $55^{\circ} \mathrm{C}$. Growth occurred over a wide range of salinity, from a minimum of $12 \%(\mathrm{w} / \mathrm{v})$ for $\mathrm{C} 23^{\mathrm{T}}$ or $14 \%(\mathrm{w} / \mathrm{v})$ for HBSQ001, up to saturation. From 18-36\% salinity, the growth profiles of both isolates were relatively flat and did not show a steep rise and fall around an optimum concentration. The optimum salinity was $18 \%(\mathrm{w} / \mathrm{v})$ for HBSQ001 and C23 ${ }^{\mathrm{T}}$. Neither strain required magnesium ions, but growth was poor in their absence. Optimum growth varied both by strain and $\mathrm{Mg}^{2+}$-associated anion. $\mathrm{C} 23^{\mathrm{T}}$ had no specific optimum for $\mathrm{MgCl}_{2}$, but concentrations above $1 \mathrm{M} \mathrm{MgCl}_{2}$ yielded higher cell densities than lower $\mathrm{Mg}^{2+}$ concentrations, while growth peaked at 0.4-0.6 M MgSO 4 . HBSQ001 grew optimally at $0.2 \mathrm{M}$ $\mathrm{MgCl}_{2}$, but required $0.6 \mathrm{M} \mathrm{MgSO}_{4}$ to reach the same density. In both strains, growth declined markedly at high $\mathrm{MgCl}_{2}$ concentrations compared with $\mathrm{MgSO}_{4}$, suggesting that the high chloride ion concentration $(>5 \mathrm{M})$ may have been inhibitory.

The two isolates had similar responses to $\mathrm{pH}$, exhibiting growth over the range 5.5-8.5. Optimum growth was at pH 6.5 for $\mathrm{C}^{2} 3^{\mathrm{T}}$ and $\mathrm{pH} 7.0$ for HBSQ001. Both SHOW strains were sensitive to the antibiotics anisomycin, chloramphenicol, erythromycin, novobiocin, rifampicin, simvastatin and tetracycline. They were resistant to ampicillin, bacitracin, cycloheximide, kanamycin, mycostatin, neomycin and streptomycin.

As shown in Fig. 2, the mobilities of the polar lipids detected by TLC were identical in the two isolates, although the proportion of phosphatidylglycerol (PG) observed in the HBSQ001 extract was lower than that in the $\mathrm{C} 23^{\mathrm{T}}$ sample. While visible in the original TLC, the PG spot for HBSQ001 did not reproduce in the photograph (Fig. 2, lane 4). In addition to PG and phosphatidylglycerophosphate methyl ester (PGP-Me), the isolates possessed a glycolipid that cochromatographed with S-DGD-1 (Fig. 2, lanes 4 and 5), a lipid that occurs in Haloferax species (lanes 1 and 2). This is consistent with previous data derived from the extraction of lipids from natural samples containing almost pure populations of SHOW cells (Oren et al., 1996).

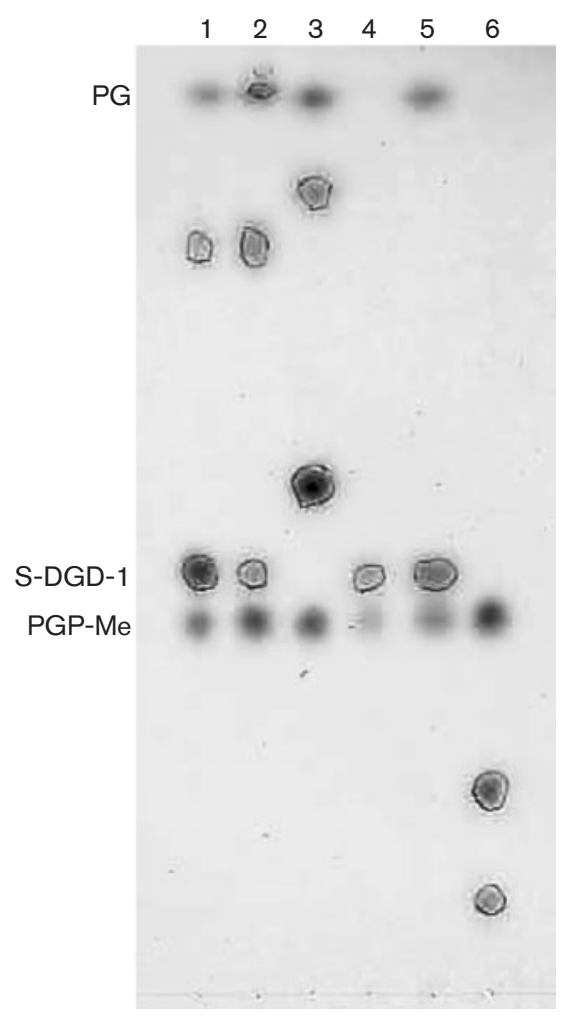

Fig. 2. TLC of polar lipids of $H f x$. mediterranei ATCC $33500^{\top}$ (lane 1), Hfx. volcanii NCIMB 2012 ${ }^{\top}$ (2), Hgm. borinquense JCM $10706^{\top}$ (3), strain HBSQ001 (4), strain $\mathrm{C}_{23}^{\top}$ (5) and Hbt. salinarum NRC-1 (6). The origin is at the bottom. PG, Phosphatidylglycerol; PGP-Me, phosphatidylglycerophosphate methyl ester; S-DGD-1, sulfated diglycosyl diether lipid. Glycolipids were detected as purple spots and circled in pencil. Lane 4 showed a visible but faint PG spot that did not reproduce in the photograph. Cells were grown as described in Methods. 
Table 1. DNA $G+C$ content and DNA-DNA relatedness between strains $\mathrm{C}_{2} 3^{\top}$ and HBSO001

\begin{tabular}{|lccc|}
\hline Fixed strain & $\begin{array}{c}\text { DNA G+C } \\
\text { content (mol\%) }\end{array}$ & \multicolumn{2}{c|}{$\begin{array}{c}\text { DNA-DNA hybridization } \\
\text { (\%) with labelled strain: }\end{array}$} \\
\cline { 3 - 4 } & & C23 $^{\text {T }}$ & HBSQ001 \\
\hline $\mathrm{C} 23^{\mathrm{T}}$ & 46.9 & 100 & 81.1 \\
HBSQ001 & 46.9 & 80.3 & 100 \\
Htg. turkmenica & 62.9 & 0.2 & 0.2 \\
JCM 9101 & & & \\
\hline
\end{tabular}

The DNA G + C content of both isolates was $46.9 \mathrm{~mol} \%$, and whole-genome DNA-DNA hybridization gave a relatedness of $\sim 80 \%$ (Table 1 ). Their $16 \mathrm{~S}$ rRNA gene sequences were almost identical, with only 2 base differences. These results indicate they are members of the same species. Phylogenetic tree reconstructions placed the two SHOW sequences in a separate clade within the Halobacteriaceae (Fig. 3). Although not shown in this figure, this clade also contained environmental clone sequences from SHOW organisms, including GenBank accession no. X84084 (Antón et al., 1999). The closest cultivated isolate to this clade was T1.3 (93.2\%), isolated from a salt mine (McGenity et al., 2000) (not shown). Among the recognized members of the Halobacteriaceae, the closest relative was Hgm. borinquense PR $3^{\mathrm{T}}$ (91.2\% sequence similarity). The $16 \mathrm{~S}$ rRNA gene sequence similarity to $H f x$. volcanii NCIMB $2012^{\mathrm{T}}(90.3 \%)$, Hrr. sodomense ATCC $33755^{\mathrm{T}}(85.6 \%)$ and Htg. turkmenica ATCC $51198^{\mathrm{T}}(87 \%)$, the control organism used in the DNA-DNA hybridization, was much lower.

The phenotypic characterization and phylogenetic data support the placement of isolates $\mathrm{C} 23^{\mathrm{T}}$ and HBSQ001 in a

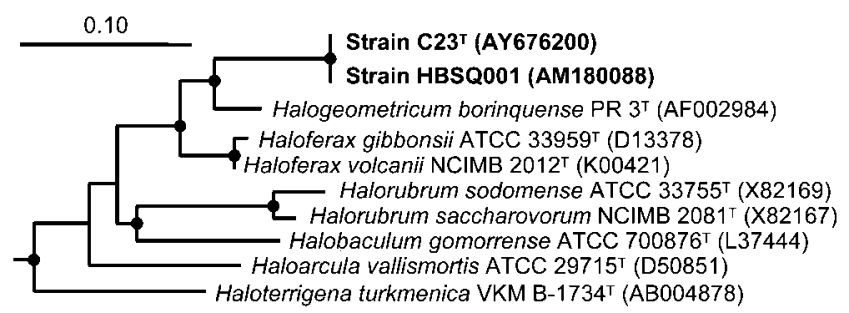

Fig. 3. Phylogenetic tree reconstruction based on complete or nearly complete 16S rRNA gene sequences (sequence accession numbers in parentheses). The tree shown was derived by maximum-likelihood (using the ARB package). Bar, 0.1 expected nucleotide substitutions per site. Bootstrap values (using distance matrix methods) were derived from 1000 replicates and significant nodes $(>75 \%)$ are indicated by filled circles at branch points. The outgroup sequences consisted of sequences representing most of the other genera of the Halobacteriaceae as well as that of Methanosaeta concilii ATCC $35969^{\top}$ (GenBank accession no. X16932.1) (not shown). novel species and a new genus within the Halobacteriaceae, for which we propose the name Haloquadratum walsbyi gen. nov., sp. nov.

\section{Description of Haloquadratum gen. nov.}

Haloquadratum (Ha.lo.quad.ra'tum. Gr. masc. n. hals, haloes salt; L. neut. n. quadratum square; N.L. neut. n. Haloquadratum salt square).

Flat, square cells that usually contain gas vesicles and PHA storage granules. Aerobic heterotrophs. Oxidase and catalase tests are negative. Cells stain Gram-negative. Phylogenetically belonging to the family Halobacteriaceae. Habitat: salt lakes and saltern crystallizer ponds. The DNA $\mathrm{G}+\mathrm{C}$ content of the type species is $46.9 \mathrm{~mol} \%$. The type species is Haloquadratum walsbyi. Following the published guidelines (Oren \& Ventosa, 2000), we propose the threeletter genus abbreviation $\mathrm{Hqr}$.

\section{Description of Haloquadratum walsbyi sp. nov.}

Haloquadratum walsbyi (wals'by.i. N.L. gen. masc. n. walsbyi of Walsby, named after A. E. Walsby, who first published observations on this organism).

Displays the following properties in addition to those given in the genus description. Cells are square $(\sim 2 \times 2 \mu \mathrm{m})$ and flat $(0.2 \mu \mathrm{m}$ thick $)$ and can form large sheets. Under suboptimal conditions, such as reduced salinity, they show flat, pleomorphic forms. Colonies on agar medium are iridescent pink with an entire edge. Strictly aerobic; only oxygen is used as the final electron acceptor. Cannot utilize nitrate or DMSO as alternative electron acceptors. Does not grow anaerobically on L-arginine. Growth occurs at pH $6.0-8.5,25-45^{\circ} \mathrm{C}$ and $14-36 \%$ (w/v) NaCl. Halophilic; cells lyse immediately in distilled water and a minimum of $\sim 14 \%(\mathrm{w} / \mathrm{v})$ salts is required for growth. Optimal growth occurs under neutrophilic to alkaliphilic conditions, above $18 \%$ salinity. Capable of growing in defined media, but is severely restricted in the substrates utilized. Grows best on pyruvate as sole carbon source. No growth enhancement occurs with acetate, alanine, arabinose, arginine, aspartate, benzoate, betaine, butanol, butyrate, cellobiose, citrate, ethanol, formate, fructose, fumarate, galactose, galacturonate, gluconuronate, glucose, glycerol, glycine, glycolate, lactate, lactose, leucine, lysine, malate, malonate, mannitol, mannose, methanol, propanol, propionate, ribose, serine, succinate, sucrose, tartrate, threonine, urea, valine or xylose at $10 \mathrm{mM}$ or cellulose, chitin or starch at $0.1 \%(\mathrm{w} / \mathrm{v})$ as the sole carbon and energy source. Acid is not produced from carbohydrate utilization. Negative for $\beta$-galactosidase and indole production. Sensitive to anisomycin, chloramphenicol, erythromycin, novobiocin, rifampicin, simvastatin and tetracycline and resistant to ampicillin, bacitracin, cycloheximide, kanamycin, mycostatin, neomycin and streptomycin at $50 \mu \mathrm{g} \mathrm{ml}^{-1}$. The polar lipids are $\mathrm{C}_{20} \mathrm{C}_{20}$ derivatives of PG, PGP-Me and S-DGD-1. The DNA G $+\mathrm{C}$ content of 
the two known strains is $46.9 \mathrm{~mol} \%$. Both strains were isolated from solar saltern crystallizer ponds.

The type strain is $\mathrm{C} 23^{\mathrm{T}}\left(=\mathrm{JCM} 12705^{\mathrm{T}}=\mathrm{DSM} 16854^{\mathrm{T}}\right)$. Strain HBSQ001 (=JCM $12895=$ DSM 16790) is a reference strain.

\section{ACKNOWLEDGEMENTS}

The authors thank Professor Dr Hans G. Trüper for his advice regarding nomenclature. We thank Dr Jane Ding for her help in writing a module of measuring the distance between membrane layers. D. G. B. was supported by an Australian Post-graduate Award. M. L. D.-S. was supported by a University of Melbourne MRGS award in 2005 and by the Department of Microbiology and Immunology. G. J. was supported by NIH grant R01 AI067548. H. B. was supported by a grant from the Netherlands Organization of Science NWO/ALW/NPP-851.20.023.

\section{REFERENCES}

Antón, J., Llobet-Brossa, E., Rodríguez-Valera, F. \& Amann, R. (1999). Fluorescence in situ hybridization analysis of the prokaryotic community inhabiting crystallizer ponds. Environ Microbiol 1, 517-523.

Antón, J., Rossello-Mora, R., Rodríguez-Valera, F. \& Amann, R. (2000). Extremely halophilic bacteria in crystallizer ponds from solar salterns. Appl Environ Microbiol 66, 3052-3057.

Antón, J., Oren, A., Benlloch, S., Rodríguez-Valera, F., Amann, R. \& Rosselló-Mora, R. (2002). Salinibacter ruber gen. nov., sp. nov., a novel, extremely halophilic member of the Bacteria from saltern crystallizer ponds. Int J Syst Evol Microbiol 52, 485-491.

Benlloch, S., Martínez-Murcia, A. J. \& Rodríguez-Valera, F. (1995). Sequencing of bacterial and archaeal 16S rRNA genes directly amplified from a hypersaline environment. Syst Appl Microbiol 18, 574-581.

Benlloch, S., Acinas, S. G., Antón, J., López-López, A., Luz, S. P. \& Rodríguez-Valera, F. (2001). Archaeal biodiversity in crystallizer ponds from a solar saltern: culture versus PCR. Microb Ecol 41, 12-19.

Bolhuis, H., te Poele, E. M. \& Rodriguez-Valera, F. (2004). Isolation and cultivation of Walsby's square archaeon. Environ Microbiol 6, 1287-1291.

Bolhuis, H., Palm, P., Wende, A., Falb, M., Rampp, M., RodriguezValera, F., Pfeiffer, F. \& Oesterhelt, D. (2006). The genome of the square archaeon Haloquadratum walsbyi: life at the limits of water activity. BMC Genomics 7, 169.

Burns, D. G., Camakaris, H. M., Janssen, P. H. \& Dyall-Smith, M. L. (2004a). Combined use of cultivation-dependent and cultivationindependent methods indicates that members of most haloarchaeal groups in an Australian crystallizer pond are cultivable. Appl Environ Microbiol 70, 5258-5265.

Burns, D. G., Camakaris, H. M., Janssen, P. H. \& Dyall-Smith, M. L. (2004b). Cultivation of Walsby's square haloarchaeon. FEMS Microbiol Lett 238, 469-473.

Dyall-Smith, M. L. (2006). The Halohandbook: Protocols for Halobacterial Genetics. http://www.microbiol.unimelb.edu.au/ people/dyallsmith/HaloHandbook

Ezaki, T., Hashimoto, Y. \& Yabuuchi, E. (1989). Fluorometric deoxyribonucleic acid-deoxyribonucleic acid hybridization in microdilution wells as an alternative to membrane filter hybridization in which radioisotopes are used to determine genetic relatedness among bacterial strains. Int J Syst Bacteriol 39, 224-229.
Gerhardt, P., Murray, R. G. E., Wood, W. A. \& Krieg, N. R. (editors) (1994). Methods for General and Molecular Bacteriology. Washington, DC: American Society for Microbiology.

Gutierrez, M. C., Kamekura, M., Holmes, M. L., Dyall-Smith, M. L. \& Ventosa, A. (2002). Taxonomic characterization of Haloferax sp. ("H. alicantei") strain Aa 2.2: description of Haloferax lucentensis sp. nov. Extremophiles 6, 479-483.

Janssen, P. H., Schuhmann, A., Morchel, E. \& Rainey, F. A. (1997). Novel anaerobic ultramicrobacteria belonging to the Verrucomicrobiales lineage of bacterial descent isolated by dilution culture from anoxic rice paddy soil. Appl Environ Microbiol 63, 1382-1388.

Kamekura, M. (1993). Lipids of extreme halophiles. In The Biology of Halophilic Bacteria, pp. 135-161. Edited by R. H. Vreeland \& L. I. Hochstein. Boca Raton, FL: CRC Press.

Ludwig, W., Strunk, O., Westram, R., Richter, L., Meier, H., Yadhukumar, Buchner, A., Lai, T., Steppi, S. \& other authors (2004). ARB: a software environment for sequence data. Nucleic Acids Res 32, 1363-1371.

Maturrano, L., Santos, F., Rosselló-Mora, R. \& Antón, J. (2006). Microbial diversity in Maras salterns, a hypersaline environment in the Peruvian Andes. Appl Environ Microbiol 72, 3887-3895.

McGenity, T. J., Gemmell, R. T., Grant, W. D. \& Stan-Lotter, H. (2000). Origins of halophilic microorganisms in ancient salt deposits. Environ Microbiol 2, 243-250.

McIntosh, R., Nicastro, D. \& Mastronarde, D. (2005). New views of cells in 3D: an introduction to electron tomography. Trends Cell Biol 15, 43-51.

Nuttall, S. D. \& Dyall-Smith, M. L. (1993). HF1 and HF2: novel bacteriophages of halophilic archaea. Virology 197, 678-684.

Oren, A. (2002). Molecular ecology of extremely halophilic Archaea and Bacteria. FEMS Microbiol Ecol 39, 1-7.

Oren, A. \& Ventosa, A. (2000). International Committee on Systematic Bacteriology Subcommittee on the taxonomy of Halobacteriaceae. Minutes of the meetings, 16 August 1999, Sydney, Australia. Int J Syst Evol Microbiol 50, 1405-1407.

Oren, A., Duker, S. \& Ritter, S. (1996). The polar lipid composition of Walsby's square bacterium. FEMS Microbiol Lett 138, 135-140.

Oren, A., Ventosa, A. \& Grant, W. D. (1997). Proposed minimal standards for description of new taxa in the order Halobacteriales. Int J Syst Bacteriol 47, 233-238.

Parkes, K. \& Walsby, A. E. (1981). Ultrastructure of a gas-vacuolate square bacterium. J Gen Microbiol 126, 503-506.

Porter, K., Kukkaro, P., Bamford, J. K., Bath, C., Kivelä, H. M., DyallSmith, M. L. \& Bamford, D. H. (2005). SH1: a novel, spherical halovirus isolated from an Australian hypersaline lake. Virology 335, 22-33.

Stoeckenius, W. (1981). Walsby's square bacterium: fine structure of an orthogonal procaryote. J Bacteriol 148, 352-360.

Tamaoka, J. (1994). Determination of DNA base composition. In Chemical Methods in Prokaryotic Systematics, pp. 463-470. Edited by M. Goodfellow \& A. G. O’Donnell. Chichester: Wiley.

Torreblanca, M., Rodriguez-Valera, F., Juez, G., Ventosa, A., Kamekura, M. \& Kates, M. (1986). Classification of non-alkaliphilic halobacteria based on numerical taxonomy and polar lipid composition, and description of Haloarcula gen. nov. and Haloferax gen. nov. Syst Appl Microbiol 8, 89-99.

Walsby, A. E. (1980). A square bacterium. Nature 283, 69-71.

Widdel, F., Kohring, G.-W. \& Mayer, F. (1983). Studies on dissimilatory sulfate-reducing bacteria that decompose fatty acids. III. Characterization of the filamentous gliding Desulfonema limicola gen. nov. sp. nov., and Desulfonema magnum sp. nov. Arch Microbiol 134, 286-294. 